\title{
PENYEIMBANGAN LINTASAN PRODUKSI DENGAN METODE HEURISTIK (STUDI KASUS PT XYZ MAKASSAR)
}

\author{
SAIFUL, MULYADI, DAN TRI MUHADI RAHMAN \\ Program Studi Teknik Industri, Jurusan Teknik Mesin, Fakultas Teknik, Universitas Hasanuddin \\ Jl. Perintis Kemerdekaan Km.10 Makassar, Sulawesi Selatan 90245
}

Surel: saiful.ti@gmail.com, mulyadihambali@ymail.com, dhyopatra@gmail.com

\begin{abstract}
ABSTRAK
PT XYZ merupakan salah satu perusahaan yang bergerak di bidang industri mebel. Masalah yang dihadapi perusahaan adalah adanya ketidakseimbangan di lintasan produksi akibat ketidakmerataan pembagian beban kerja di setiap stasiun kerja. Hal ini menyebabkan performansi keseimbangan lintasan (line performance) menjadi kurang baik. Untuk menyelesaikan permasalahan ini perlu dilakukan penyeimbangan lintasan produksi. Hal ini dapat dilakukan dengan metode line balancing yaitu metode penugasan sejumlah pekerjaan yang saling berkaitan dalam satu lintasan produksi sehingga setiap stasiun kerja memiliki waktu yang tidak melebihi waktu siklus dari stasiun kerja tersebut. Metode line balancing yang digunakan adalah metode heuristik yang terdiri dari: metode bobot posisi (Ranked Positional Weight), metode pembebanan berurut (Large Candidate Rule), dan metode pendekatan wilayah (Region Approach). Dari ketiga metode Heuristik yang digunakan sebagai solusi penyeimbangan lintasan, terjadi perbaikan performansi dengan nilai yang sama pada lintasan produksi. Nilai efisiensi lintasan (line efficiency) meningkat menjadi 94,07\% dari 62,71\% pada kondisi awal. Nilai keseimbangan waktu senggang (balance delay) turun menjadi 5,92 \% dari 37,28\% pada kondisi awal. Waktu menganggur (idle time) turun menjadi 12,39 menit dari 116,87 menit pada kondisi awal. Nilai smoothness index juga turun menjadi 7,44 dari 64,67 pada kondisi awal.
\end{abstract}

Kata Kunci: keseimbangan lintasan, performasi lintasan, metode heuristik

\begin{abstract}
$P T X Y Z$ is one of the company which refers to furniture industries sector. The problem which faced by this company is unbalance of the production line which is caused by the unequal of work responsibility distribution in each work station. This problem caused the performance of line balance doesn't work properly. To solve this problem we need to do the line balancing of production line. It can be done by line balancing methode that assigns a number of work which is related in one production line until each work station has efficient time which is not more than the cycle time of the work station. Line balancing methode that used is heuristic methode which is devided into ranked positional weight methode, large candidate rule methode, and region approach methode. From those three heuristic methode that used as solution of line balancing, there was improvement happenned with the same value in doors of production line. Line efficiency increased into $94,07 \%$ from $62,71 \%$ at the beginning condition. Balance delay increased into 5,92\% from $37,28 \%$ at the beginning condition. The idle time descreased into 12,39 minutes from 116,87 minutes at the beginning condition. The smoothness index descreased into 7,44 from 64,67 at the beginning condition.
\end{abstract}

Key words: line balancing, line performance, heuristic method

\section{PENDAHULUAN}

Dalam menghadapi permasalahan dunia industri serta persaingan global, efisiensi, efektivitas, dan produktivitas yang tepat bagi operasi industri merupakan faktor kunci bagi setiap industri manufaktur agar mampu bersaing secara kompetitif (Sofjan, 2011). Upaya yang dapat dilakukan untuk mendukung hal tersebut yakni dengan melakukan suatu perencanaan dan perancangan sistem produksi yang tepat 
yaitu dengan prinsip keseimbangan lintasan produksi (Kucukkoc and Zhang, 2015), dimana keseimbangan lintasan ini dipengaruhi oleh beberapa faktor seperti kinerja operator, tata letak yang tepat, dan ada tidaknya antrian bahan.

Masalah yang dihadapi oleh perusahaan yang menjadi objek penelitian ini adalah adanya ketidakseimbangan di lintasan produksi akibat ketidakmerataan pembagian beban kerja di setiap stasiun kerja. Hal ini menyebabkan performansi keseimbangan lintasan menjadi kurang baik. Untuk menyelesaikan permasalahan ini perlu dilakukan penyeimbangan lintasan produksi. Hal ini dapat dilakukan dengan metode heuristik (Moreira et al., 2015). Metode heuristik diantaranya Ranked Positional Weight (RPW), Large Candidate Rule (LCR), dan Region Approach (RA).

Dengan pendekatan ini diharapkan dapat meningkatkan produktivitas perusahaan dengan menghasilkan output optimal. Peningkatan produktivitas dapat dicapai dengan menekan sekecil-kecilnya segala biaya termasuk dalam memanfaatkan sumber daya manusia (do the right thing) dan meningkatkan keluaran sebesarsebesarnya (do the thing right). Dengan kata lain bahwa produktivitas merupakan pencerminan dari tingkat efisiensi dan efektivitas kerja secara total. Efisiensi adalah rasio output terhadap input, atau jumlah output per unit input. Efektivitas ditentukan oleh hubungan antara output yang dihasilkan oleh suatu pusat tanggung jawab dengan tujuannya.

PT XYZ Makassar adalah salah satu perusahaan yang bergerak di bidang industri mebel. Dalam proses produksi daun pintu ada banyak komponen yang harus dirakit. Lintasan produksi yang tidak seimbang akan menyebabkan performansi keseimbangan lintasan menjadi kurang baik. Hal ini menimbulkan idle time yang besar dan penumpukan barang setengah jadi (work in process) pada beberapa stasiun kerja (Sternatz, 2015). Ketidakseimbangan pembagian kerja dari operator juga menyebabkan perbedaan waktu penyelesaian operasi tiap stasiun kerja sehingga nilai efisiensi lintasan produksi pun menjadi rendah.

Untuk mengatasi permasalahan yang dihadapi, perlu dilakukan penyeimbangan pada lintasan produksi dengan menerapkan metode heuristik. Metode ini diharapkan mampu memberikan solusi sebagai alternatif untuk meningkatkan perfomansi keseimbangan lintasan produksi, sehingga proses produksi daun pintu akan lebih efisien, efektif, dan produktif.

\section{METODE}

Dalam penelitian ini, beberapa tahap dilalui hingga memperoleh hasil, diantaranya adalah tahap identifikasi, tahap pengumpulan data, tahap pengolahan data, tahap analisis hasil pengolahan data, dan tahap penarikan kesimpulan. Pada tahap identifikasi, dilakukan identifikasi indikator yang akan dijadikan tolak ukur bagi implementasi konsep penyeimbangan lini (Line Balancing). Indikator inilah yang akan diketahui penerapannya dan akan dijadikan dasar dalam pengolahan data.

Dalam tahap pengumpulan data, dilakukan survey ke PT XYZ Makassar untuk memperoleh data primer berupa data waktu operasi dari setiap elemen kerja dan data sekunder berupa data pelengkap dengan melakukan wawancara dan pengamatan langsung (Visual Motion Study). Data itu kemudian diolah sehingga diperoleh waktu baku dari setiap elemen kerja dengan memperhatikan rating factor dan allowance. Rumus untuk menghitung waktu standar, (Wignjosoebroto, 2003) yaitu :

$\mathrm{Wn}=\mathrm{Ws} \times$ rating factor.

$\mathrm{Wb}=W n \times \frac{100 \%}{100 \%-\text { Allowance }}$.

dimana, (Ws) adalah waktu siklus/waktu operasi, (Wn) adalah waktu normal, dan (Wb) adalah waktu baku/waktu standar.

Langkah selanjutnya menghitung performansi lintasan yang akan memberi gambaran awal dari kondisi lintasan pada produksi daun 
pintu. Performansi lintasan ini meliputi efisiensi lintasan, efisiensi stasiun kerja, waktu menganggur, keseimbangan waktu senggang, dan smoothness index. Untuk menghitung efisiensi lintasan digunakan rumus 3 (Nasution, 2008):

$\mathrm{EL}=\frac{\sum \mathrm{Wi}}{\mathrm{n} \times \mathrm{Ws}} \mathrm{X} 100 \%$

Dimana $\sum$ Wi adalah total waktu operasi, $\mathrm{n}$ adalah jumlah stasiun kerja, dan Ws adalah waktu siklus aktual. Selanjutnya untuk menghitung efisiensi stasiun kerja (Station Efficiency) digunakan rumus 4 .

$\mathrm{SE}=\frac{\mathrm{Wi}}{\mathrm{Ws}} \times 100 \%$

Dimana Wi adalah waktu operasi elemen kerja ke-i. Rumus untuk menghitung waktu menganggur (idle time) yaitu :

$\mathrm{IT}=(\mathrm{n} \times \mathrm{Ws})-\sum_{\mathrm{i}=1}^{\mathrm{n}} \mathrm{Wi}$

Kemudian untuk menghitung keseimbangan waktu senggang (balance delay) digunakan rumus 6.

$\mathrm{BD}=\frac{\mathrm{n} \times \mathrm{W}_{\mathrm{s}}-\sum_{i=1}^{\mathrm{n}} \mathrm{Wi}_{\mathrm{i}}}{\mathrm{n} \times \mathrm{W}_{\mathrm{s}}} \times 100 \%$

Rumus untuk menghitung smoothness index yaitu (Scholl et al., 2006) :

$\mathrm{SI}=\sqrt{\sum_{\mathrm{i}=1}^{\mathrm{n}}(\mathrm{Ws}-\mathrm{Wi})^{2}}$

Performansi lintasan ini menjadi indikator dari keseimbangan lintasan di lini produksi daun pintu. Kemudian dilakukan perbaikan dengan menggunakan beberapa metode Line Balancing sehingga diperoleh hasil yang berbeda dari kondisi aktual. Metode keseimbangan lintasan yang digunakan adalah metode heuristik yang terdiri dari metode Ranked Positional Weight, $(R P W)$, metode Large Candidate Rule ( $L C R)$, dan metode Region Approach (RA).

Pada tahap analisis hasil pengolahan data, akan dibandingkan performansi lintasan antara kondisi aktual dengan metode perbaikan yang diajukan. Setelah menganalisis perbandingan performansi lintasan tersebut, maka akan masuk ke dalam tahap penarikan kesimpulan.

\section{HASIL DAN PEMBAHASAN}

Berdasarkan hasil pengamatan langsung pada bagian produksi daun pintu di PT XYZ Makassar maka diperoleh data waktu operasi elemen kerja di setiap stasiun kerja seperti pada Tabel 1.

Pada Tabel 1 menunjukkan bahwa terdapat pengelompokan elemen kerja pada masing-masing stasiun kerja. Di dalam proses produksi terdapat 6 stasiun kerja yang terdiri dari 11 elemen kerja. Stasiun 1, 2, dan 3 hanya terdiri dari satu elemen kerja. Sementara stasiun 4 dan 5 memiliki masing-masing 3 elemen kerja. Jumlah operator pada stasiun kerja yakni masing-masing 1 orang operator. Data waktu operasi tersebut kemudian diolah sehingga diperoleh waktu standar atau waktu baku dengan memperhatikan rating factor dan allowance. Rating factor yang digunakan adalah westinghouse dan allowance berdasarkan faktor-faktor yang berpengaruh. Rekapitulasi hasil perhitungan waktu baku dapat dilihat pada Tabel 2.

Tabel 2 menjelaskan bahwa untuk masingmasing elemen kerja dihitung waktu bakunya berdasarkan faktor penyesuaian dan faktor kelonggaran. Total waktu operasi yakni 196,57 menit dengan waktu operasi terbesar yaitu pada stasiun kerja 4 selama 52,24 menit.

\section{Hasil Performansi Keseimbangan Lintasan Pada Kondisi Aktual}

Kondisi aktual pada lintasan produksi daun pintu seperti pada Gambar 1. Hasil perhitungan nilai performansi keseimbangan lintasan yakni sebagai berikut :

Efisiensi Lintasan

$=\frac{\sum_{\mathrm{i}=1}^{\mathrm{n}} \mathrm{Wi}_{\mathrm{i}}}{\mathrm{n} \times \mathrm{W}_{\mathrm{s}}} \times 100 \%$ 
Tabel 1. Data rata-rata waktu operasi tiap elemen kerja

\begin{tabular}{|c|c|c|c|}
\hline $\begin{array}{l}\text { Stasiun } \\
\text { Kerja }\end{array}$ & $\begin{array}{c}\text { No. } \\
\text { Elemen } \\
\text { Kerja } \\
\end{array}$ & Jenis Elemen Kerja & $\begin{array}{c}\text { Waktu Operasi } \\
\text { Elemen Kerja } \\
\text { (Menit) }\end{array}$ \\
\hline 1 & 1 & Pengerutan dan perataan kayu & 17,93 \\
\hline 2 & 2 & $\begin{array}{l}\text { Pengukuran panjang kayu berdasarkan pola komponen } \\
\text { frame dan panel }\end{array}$ & 9,13 \\
\hline 3 & 3 & Pemotongan kayu yang sudah diukur & 9,16 \\
\hline \multirow{3}{*}{4} & 4 & $\begin{array}{l}\text { Pembuatan tenon dan mortise untuk frame horizontal } \\
\text { (rail) }\end{array}$ & 13,80 \\
\hline & 5 & Pembuatan tenon dan mortise untuk frame vertikal & 12,06 \\
\hline & 6 & Pembuatan panel pintu & 15,16 \\
\hline \multirow{3}{*}{5} & 7 & $\begin{array}{l}\text { Pembuatan profile pada frame yang akan berhubungan } \\
\text { dengan panel }\end{array}$ & 8,26 \\
\hline & 8 & Pembuatan alur/groove untuk tempat memasukkan panel & 10,43 \\
\hline & 9 & Perangkaian seluruh komponen frame dan panel & 20,73 \\
\hline \multirow{2}{*}{6} & 10 & Penghalusan pintu & 30,67 \\
\hline & 11 & Pelapisan dengan polytur & 6,87 \\
\hline
\end{tabular}

Tabel 2. Rekapitulasi Data Waktu Baku Elemen Kerja

\begin{tabular}{cccccccc}
\hline $\begin{array}{c}\text { Stasiun } \\
\text { Kerja }\end{array}$ & $\begin{array}{c}\text { Elemen } \\
\text { Kerja }\end{array}$ & $\begin{array}{c}\text { Waktu } \\
\text { Siklus } \\
\text { (Menit) }\end{array}$ & $\begin{array}{c}\text { Rating } \\
\text { Factor }\end{array}$ & $\begin{array}{c}\text { Waktu } \\
\text { Normal } \\
\text { (Menit) }\end{array}$ & Allowance & $\begin{array}{c}\text { Waktu } \\
\text { Baku } \\
\text { (Menit) }\end{array}$ & $\begin{array}{c}\text { Total Waktu } \\
\text { Operasi Stasiun } \\
\text { Kerja (Menit) }\end{array}$ \\
\hline 1 & 1 & 17,93 & 1,09 & 19,54 & $16 \%$ & 23,26 & 23,26 \\
2 & 2 & 9,13 & 1.08 & 9,86 & $13 \%$ & 11,33 & 11,33 \\
3 & 3 & 9,16 & 1,1 & 10,07 & $16 \%$ & 11,98 & 11,98 \\
& 4 & 13,8 & 1,12 & 15,45 & $13 \%$ & 17,75 & \\
4 & 5 & 12,06 & 1,12 & 13,5 & $13 \%$ & 15,51 & 52,24 \\
& 6 & 15,16 & 1,09 & 16,52 & $13 \%$ & 18,98 & \\
& 7 & 8,26 & 1,09 & 9 & $14 \%$ & 10,46 & 49,47 \\
& 8 & 10,43 & 1,09 & 11,36 & $13 \%$ & 13,05 & \\
& 9 & 20,73 & 1,09 & 22,59 & $13 \%$ & 25,96 & \\
& 10 & 30,67 & 1,09 & 33,43 & $16 \%$ & 39,79 & \\
\hline
\end{tabular}

$=\frac{196,57}{6 \times 52,24} \times 100 \%$

$=62,71 \%$

Idle Time

$=(\mathrm{n} \times \mathrm{Ws})-\sum_{i=1}^{\mathrm{n}} \mathrm{Wi}_{\mathrm{i}}$

$=(6 \times 52,24)-196,57$

$=116,87$ menit

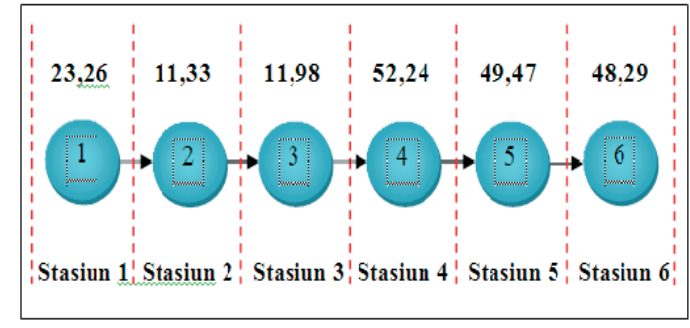

Gambar 1. Kondisi Lintasan Aktual 
Balance Delay

$$
\begin{aligned}
& =\frac{(\mathrm{n} \times \mathrm{Ws}) \cdot \sum_{\mathrm{i}=1}^{\mathrm{n}} \mathrm{Wi}}{\mathrm{n} \times \mathrm{W}_{\mathrm{s}}} \times 100 \% \\
& =\frac{(6 \times 52,24) \cdot 196,57}{6 \times 52,24} \times 100 \% \\
& =37,28 \% \\
& S I=\sqrt{\sum_{\mathrm{i}=1}^{\mathrm{n}}(\mathrm{Ws}-\mathrm{Wi})^{2}} \\
& =\sqrt{(52,24-23,26)^{2}+(52,24-11,33)^{2}++(52,24-48,29)^{2}} \\
& =64,47
\end{aligned}
$$

\section{Hasil Performansi Keseimbangan Lintasan Setelah Perbaikan Dengan Metode Heuristik}

Berdasarkan hasil penyeimbangan lintasan dengan menggunakan metode heuristik yang terdiri dari metode Ranked Positional Weight, metode Largest Candidate Rules, dan metode Region Approach dengan tahapan sebagai berikut:

a. Metode Ranked Positional Weight (RPW)

- Membuat precedence diagram

- Menentukan waktu siklus

- Menentukan jumlah stasiun kerja

- Memindahkan jaringan kerja menjadi matriks pendahulu

- Menghitung bobot posisi tiap stasiun kerja

- Menggabungkan stasiun kerja berdasarkan metode RPW

- Perhitungan indikator perfomansi lintasan produksi

b. Largest Candidate Rules LCR)

- Membuat precedence diagram

- Menentukan waktu siklus

- Menentukan jumlah stasiun kerja

- Urutkan stasiun kerja berdasarkan waktu baku dari terbesar ke terkecil
- Penggabungan stasiun kerja berdasarkan metode LCR

- Perhitungan indikator perfomansi lintasan produksi

c. Region Approach (RA)

- Membuat precedence diagram

- Menentukan waktu siklus

- Menentukan jumlah stasiun kerja

- Penggabungan dalam precedence dengan berbagai cara dan mengambil hasil gabungan terbentuk yang hasilnya sama atau mendekati waktu siklus aktual

- Penggabungan stasiun kerja berdasarkan metode RA

- Perhitungan indikator perfomansi lintasan produksi

Dengan menggunakan metode usulan, perbaikan dengan mengurangi jumlah stasiun kerja dengan menggabungkan beberapa elemenelemen kerja menjadi satu stasiun kerja. Sehingga jumlah stasiun kerja yang pada kondisi awal berjumlah 6 stasiun kerja berkurang menjadi 4 stasiun kerja pada kondisi usulan. Penggabungan stasiun kerja dapat dilihat pada Tabel 3. Setelah dilakukan penggabungan stasiun kerja diperoleh kondisi lintasan produksi daun pintu seperti pada Gambar 2.

Pada Gambar 2 terlihat bahwa elemen kerja 1, 2, dan 3 digabungkan menjadi satu stasiun kerja yaitu stasiun kerja 1 . Sementara elemen kerja 4,5 dan 6 menjadi stasiun kerja 2. Diikuti elemen kerja 7,8,9 menjadi stasiun kerja 3, dan elemen kerja 10,11 menjadi stasiun kerja 4. Penggabungan elemen kerja tersebut memengaruhi total waktu operasi tiap stasiun kerja sehingga diperoleh nilai performansi keseimbangan lintasan sebagai berikut:

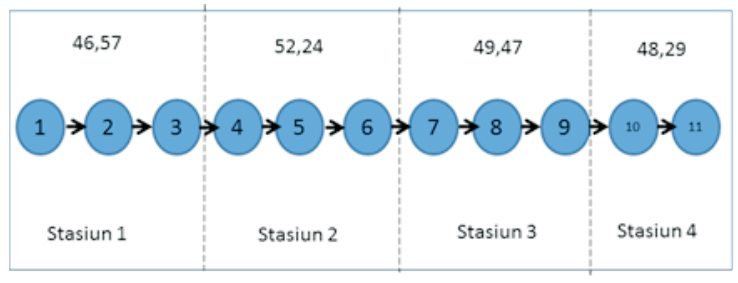

Gambar 2. Kondisi Lintasan Usulan Berdasarkan Metode Heuristik 
Tabel 3. Penggabungan Stasiun Kerja Berdasarkan Metode Heuristik (RPW, LCR, RA)

\begin{tabular}{cccc}
\hline Stasiun Kerja & Elemen Kerja & $\begin{array}{l}\text { Waktu Operasi Elemen } \\
\text { Kerja (Menit) }\end{array}$ & $\begin{array}{l}\text { Waktu Operasi Stasiun } \\
\text { Kerja (Menit) }\end{array}$ \\
\hline & 1 & 23,26 & \\
1 & 2 & 11,33 & \\
& 3 & 11,98 & \\
& 4 & 17,75 & 52,24 \\
2 & 5 & 15,51 & \\
& 6 & 18,98 & \\
& 7 & 10,46 & 49,47 \\
3 & 8 & 13,05 & 48,29 \\
& 9 & 25,96 & \\
4 & 10 & 39,79 & \\
& 11 & 8,5 & \\
\hline
\end{tabular}

Efisiensi Lintasan

$=\frac{\sum_{\mathrm{i}=1}^{\mathrm{n}} \mathrm{Wi}}{\mathrm{nxWs}} \times 100 \%$

$$
\begin{aligned}
& S I=\sqrt{\sum_{\mathrm{i}=1}^{\mathrm{n}}(\mathrm{Ws}-\mathrm{Wi})^{2}} \\
& =\sqrt{(52,24-46,57)^{2}+(52,24-52,24)^{2}+\cdots+(52,24-48,29)^{2}} \\
& =\sqrt{55,42} \\
& =7,44
\end{aligned}
$$$$
=\frac{196,57}{4 \times 52,24} \times 100 \%
$$$$
=94,07 \%
$$

Idle Time

$=\left(\mathrm{n} \times W_{s}\right)-\sum_{i=1}^{\mathrm{n}} \mathrm{Wi}$

$=(4 \times 52,24)-196,57$

$=12,39$ menit

\section{Balance Delay}

$=\frac{\mathrm{nxWs}-\sum_{\mathrm{i}=1}^{\mathrm{n}} \mathrm{Wi}}{\mathrm{n} \times \mathrm{Ws}} \times 100 \%$

$=\frac{(4 \times 52,24)-196,57}{4 \times 52,24} \times 100 \%$

$=\frac{208,96-196,57}{208,96} \times 100 \%$

$=5,92 \%$

\section{Perbandingan Hasil Performansi Keseimbangan Lintasan antara Kondisi Aktual dan Kondisi Usulan dengan Metode Heuristik}

Setelah melakukan pengolahan data berdasarkan kondisi aktual dan kondisi usulan, selanjutnya dapat dianalisis perbandingan performansi keseimbangan lintasan produksi. Perbandingan dapat dilihat pada Tabel 4.

Dari hasil perbandingan diketahui bahwa jumlah stasiun kerja pada kondisi aktual yakni sebanyak 6 stasiun kerja yang masing-masing terdiri dari 1 orang operator. Nilai performansi keseimbangan lintasan juga menunjukkan adanya masalah pada lintasan produksi daun pintu. Dimana terjadi waktu menganggur yang sangat tinggi sebesar 116,87 menit, diikuti 
Tabel 4. Perbandingan Performansi Keseimbangan Lintasan Pada Kondisi Aktual dan Kondisi Usulan

\begin{tabular}{lcccc}
\hline \multirow{2}{*}{ Perfomansi } & Awal & \multicolumn{2}{c}{ Usulan Dengan Metode Heuristik } & \\
\cline { 3 - 5 } Jumlah Stasiun Kerja & RPW & 4 & LCR & RA \\
& Stasiun I & Stasiun I & Stasiun I & 4 \\
& 1 & $1,2,3$ & $1,2,3$ & Stasiun I \\
& Stasiun II & Stasiun II & Stasiun II & Stasiun II \\
& 2 & $4,5,6$ & $4,5,6$ & $4,5,6$ \\
& Stasiun III & Stasiun III & Stasiun III & Stasiun III \\
& 3 & $7,8,9$ & $7,8,9$ & $7,8,9$ \\
& Stasiun IV & Stasiun IV & Stasiun IV & Stasiun IV \\
& $4,5,6$ & 10,11 & 10,11 & 10,11 \\
Stasiun V & & & \\
Idle Time & $7,8,9$ & & & \\
Balanced Delay & Stasiun VI & & & \\
Line Efficiency & 10,11 & & & \\
Smoothness Index & 116,87 menit & 12,39 menit & 12,39 menit & 12,39 menit \\
\hline & $37,28 \%$ & $5,92 \%$ & $5,92 \%$ & $5,92 \%$ \\
& $62,71 \%$ & $94,07 \%$ & $94,07 \%$ & $94,07 \%$ \\
& 64,67 & 7,44 & 7,44 & 7,44 \\
\hline
\end{tabular}

dengan efisiensi lintasan yang sangat rendah yakni $62,71 \%$. Keseimbangan waktu senggang juga sangat tinggi yakni $37,28 \%$ yang berbanding lurus dengan nilai smoothness index sebesar 64,67. Keseluruhan nilai performansi keseimbangan lintasan pada kondisi aktual menunjukkan adanya ketidakseimbangan pada lintasan produksi yang diakibatkan ketidakmerataan pembagian beban kerja di setiap stasiun kerja, sehingga sangat perlu dilakukan perbaikan.

Berangkat dari masalah ketidakseimbangan pada kondisi lintasan aktual maka dilakukan usulan perbaikan dengan penyeimbangan lintasan produksi menggunakan metode heuristik yang terdiri dari metode RPW, LCR, dan RA. Pada Tabel 4 jelas terlihat perbedaan yang sangat signifikan antara performansi keseimbangan lintasan pada kondisi aktual dan kondisi usulan dengan menggunakan metode heuristik. Ketiga metode heuristik yang digunakan memberikan usulan yang sama yakni melakukan pengurangan stasiun kerja dengan menggabungkan stasiun kerja menjadi 4 stasiun kerja. Stasiun kerja yang digabungkan yakni stasiun kerja 1, 2, dan 3 . Nilai performansi keseimbangan lintasan yang diperoleh pun sama. Terjadi pengurangan waktu menganggur menjadi 12,39 menit yang diikuti peningkatan efisiensi lintasan menjadi 94,07\% . Keseimbangan waktu senggang turun menjadi $5,92 \%$ yang berbanding lurus dengan smoothness indeks yang ikut turun menjadi 7,44.

Hasil ini menunjukkan bahwa semua metode usulan memberikan solusi terbaik dan dengan menerapkan metode heuristik tersebut maka masalah yang dihadapi perusahaan akan terselesaikan. Keuntungan lain yang akan diperoleh yakni pada penggunaan operator, dimana dengan mengurangi jumlah stasiun kerja maka perusahaan juga dapat mengurangi jumlah operator, sehingga biaya upah pekerja dapat direduksi. Selain itu, dengan berkurangnya waktu menganggur maka akan semakin banyak 
waktu kerja produktif yang dapat dimanfaatkan perusahaan untuk menambah jumlah produk yang dihasilkan.

\section{KESIMPULAN}

Berdasarkan hasil perhitungan perfomansi keseimbangan lintasan yang dilakukan pada lintasan produksi awal diperoleh efisiensi lintasan $62,71 \%$, balance delay sebesar $37,28 \%$, idle time sebesar 116,87 menit, smoothness index 64,67. Untuk memperbaiki masalah pada lintasan produksi maka dilakukan usulan perbaikan keseimbangan lintasan dengan menggunakan metode heuristik yang terdiri dari: Ranked Positional Weight, Largest Candidate Rule, dan Region Approach. Semua metode yang digunakan menunjukkan adanya peningkatan perfomansi. Efisiensi lintasan meningkat menjadi 94,07\%, balance delay turun menjadi 5,92 \%, idle time turun menjadi 12,39 menit, dan smoothness index turun menjadi 7,44.

\section{DAFTAR PUSTAKA}

Assauri, S., 2011. Manajemen Produksi dan Operasi, Jakarta: Lembaga Penerbit FEUI.

Kucukkoc, I. and Zhang, D.Z., 2015. Type-E Parallel Two Side Assembly Line Balancing Problem: Mathematical Model and Ant Colony Optimisation Based Approach with Optimesd Parameters. Computer \& Industrial Engineering, 84, 56-69.

Nasution, A.H., 2008. Perencanaan dan Pengendalian Produksi, Yogyakarta: Graha Ilmu.

Moreira, M.C., Miralles, C., and Costa, A., 2015. Model and Heuristics for the Assembly Line Worker Integration and Balancing Problem, Computers \& Operations Research, 54, 64-73,

Scholl, A., Becker, C., 2006. State of the Art Exact and Heuristic Solution Procedures for Simple Assembly Line Balancing, European Journal of Operational research, 168, 666-693.

Sternatz, J., 2015. The Joint Line Balancing and Material Supply Problem. International Journal of Production Economic, 159, 304-318.

Wignjosoebroto, S., 2003. Ergonomi Studi Gerak dan Waktu, Surabaya: Guna Widya. 